\title{
An anatomy of Turkish football match-fixing
}

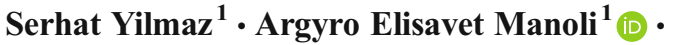 \\ Georgios A. Antonopoulos 2 (D)
}

\begin{abstract}
While discussion on corruption in sport is intensifying and football match-fixing in particular is attracting increasing attention, new fixing scandals emerge offering new accounts of actors and corrupt practices within the football industry and the level of the external threat to the sport. The scandal exposure of fixed matches in Turkey in 2011 sheds light on the fixing of 17 matches played in the 2010/11 football season and allowed for insights to the actors, structure and processes behind the fix. Following four criminal and seven disciplinary proceedings, the case is still pending appeal for its final decision, involving a total of 93 suspects and having already resulted in the exclusion of two teams from European competitions. The evidence collected by the authorities points towards a hierarchical criminal organisation led by the President of a football club that arranged and coordinated the fixing in order for his team to win the national Championship. The aim of this article is to provide an account of the organisation and coordination of match-fixing in Turkey, with its actors, specifics and criminal characteristics, while offering an examination of matchfixing for sporting success, the least documented type of match-fixing.
\end{abstract}

Keywords Match-fixing $\cdot$ Turkey $\cdot$ Organised crime $\cdot$ Corruption $\cdot$ Sport corruption

Argyro Elisavet Manoli

e.a.manoli@lboro.ac.uk

Serhat Yilmaz

s.yilmaz3@lboro.ac.uk

Georgios A. Antonopoulos

g.antonopoulos@tees.ac.uk

1 School of Sport, Exercise and Health Sciences, Loughborough University, Leicestershire LE11 3TU, UK

2 School of Social Sciences, Humanities \& Law, Teesside University, Middlesbrough, UK 


\section{Introduction}

The last ten years have seen the discussion on corruption in sport intensifying, as more incidents of corrupt and fraudulent actions within a number of sports have emerged. High profile incidents have uncovered the frequency and intensity of corruption, especially in professionalised competitive sports, such as football (Hill 2010, 2015; Haberfeld and Sheehan 2013; Brooks et al. 2013; Manoli et al. 2017) and athletics (O'Leary 2013). In the latter, a number of widely documented scandals of athletes' doping have recently surfaced, triggering further investigations into the anti-doping test regime before and during major events, such as the Olympics, and even resulting in athletes being stripped off their medals and banned from participating in future competitions (Dijkstra et al. 2016; Fincoeur et al. 2014; Paoli and Donati 2014). Corruption in football has attracted equal, if not more, attention in recent years, with prominent scandals of bribery involving high level officials (e.g. FIFA, see Jennings 2016) and cases of match-fixing in specific national contexts (e.g. Italy, see Di Ronco and Lavorgna 2015; Greece, see Manoli and Antonopoulos 2015; Manoli et al. 2017; the Netherlands, see Spapens and Olfers 2015; Poland, Portugal and Brazil, see European Commission 2012; Germany, see Feltes 2013; Haberfeld and Sheehan 2013) surfacing over and over again.

While, as recent scandals have demonstrated, corruption in sport can take many forms, match-fixing in football tends to attract the attention of both media and high profile individuals such as Ralf Mutschke, FIFA's head of security, who suggested that organised crime structures "recently switched from drug trafficking to matchfixing" (Mutschke 2013: ix-x). In his study of match-fixing in Belgian football, Declan Hill (2010) appears to be in agreement with Mutschke's statement, presenting a hierarchical, mafia-type structure within football that organises and manages the manipulation of matches on the basis of profit through gambling. On the other hand, Manoli and Antonopoulos (2015), through a detailed account of football match-fixing in Greece, describe a flat, web-type structure, formed through both long-term and short-term agreements made on the basis of either promise of reward or threat of harm. These entirely different organisational structures and incentives already captured within academia can allow us to suggest that match-fixing and its details can indeed take diverse forms and thus be manifested in various ways. Moreover, of interest are the accounts on the level of infiltration of 'organised crime' in football as this is manifested -among other- by match-fixing. In September 2012, for instance, an EU-parliament special committee on 'Organised Crime, Corruption and Money Laundering' pointed out that "sports fraud is extremely interesting for organized crime due to its relatively high revenues and low sentences"... [criminal organizations have] "deeply penetrated the football establishment”. (Fajon and Bozkurt, 2012 cited in Feltes 2013: 25). In addition, it was suggested during the hearings of the committee that "strong ties exist between the football establishment and criminal organizations especially in Eastern Europe and the Balkans. ...Criminals have infiltrated in the clubs and federations and are operating from within, while using the clubs as covers for a multitude of criminal activities" (Fajon and Bozkurt, 2012 cited in Feltes 2013: 25).

However, and despite the attention match-fixing cases have attracted, academic research on the matter is still in its infancy. In fact, one could argue that the only 
theoretical frameworks available on match-fixing actors and processes come from the two above mentioned cases: Belgian football by Hill (2009) and Greek football by Manoli and Antonopoulos (2015), which were also considered for this study. This paper examines one of the most prominent cases of match-fixing in European football, the match-fixing case of Turkish football, often referred to as 'Şike Davası', in an attempt to further our understanding of the match-fixing phenomenon and its various manifestations, as well as the level of infiltration of organised crime in football. In particular, the case examined is considered one of the biggest scandals in Turkish football, involving 93 prominent figures of the sport. Following the investigation of the Turkish police during the 2010/11 season, 31 of these individuals were imprisoned, due to their fixing related activities, initiating a number of legal battles. Rather than fixing for financial gains through betting, which has been a dominant theme of academic work in the field (Hill 2009, 2010; Manoli and Antonopoulos 2015), the case offers an appropriate context to examine match-fixing for sporting success. Fixing for sporting success refers to the manipulation of the outcome of football matches in order for the overall competition/league to be won, and by extension for the financial benefits associated with that success (e.g. from participation in Champions' League, sponsors, etc.) to be obtained (Carpenter 2014). This study hence adds to the limited academic work on match-fixing for sporting success, while offering a detailed account of the previously undocumented process of match-fixing in Turkey with its actors, specifics and criminal characteristics. In more detail, the analysis of the case focuses on the primary actors of a scheme, described in the criminal proceedings before the Turkish court, which comprised of several key individuals from one of Turkey's leading clubs, Fenerbahçe Spor Kulübü (hereafter 'Fenerbahçe') and their match-fixing activities of specific games of the Turkish Super League (the Turkish first national football division, known as 'Süper Lig') during the second half of the 2010/2011 football season. It is also important to note that this paper does not aim to explain the political dimension of the Turkish match-fixing case, which has been already analysed in great detail albeit within the country (Başaran 2013; Erkin 2015; Uzun 2015).

The paper procceds in four steps. Firstly, the overview of the case elaborating on the background and the subsequent legal and disciplinary proceedings is presented, with a view to provide a contextual setting for the analysis in the following sections. After the methodological approach adopted and the data used for the analysis are outlined, the process of match-fixing in Turkey is presented, followed by an examination of all key actors involved, including both the primary actors of the alleged 'criminal organisation' and the associated secondary actors. Finally, a discussion takes place in order to better contextualise the findings of this study.

\section{Overview of the Turkish match-fixing case}

The Turkish match-fixing case is one of the most prolific and scandalous events that has taken place in the history of football in Turkey, which was classed as the 28th best in the FIFA world ranking at the time when the scandal broke (FIFA 2017). The 
case was the result of an eight-month investigation (December 2010 to July 2011) by the Turkish authorities that involved wiretapping and technical and physical tracking of several individuals, who were suspected to form 'criminal organisations' to conduct match-fixing activities in the top two divisions of Turkish football, the Turkish Super League and the First League (known as '1. Lig'). A total of 17 matches played in the 2010/11 football season were suspected of being manipulated including 13 of the Turkish Super League and the final of the Turkish Cup (see Table 1). Consequently, on July 3rd 2011, the Turkish police ran concurrent operations in 15 different cities, making several arrests which marked the commencement of the criminal proceedings that involved a total of 93 suspects. Following police interrogations, 31 of 93 suspects were arrested and sent to prison. Among them were individuals from prominent Turkish Super League clubs including several executives of Fenerbahçe, namely its President, two Vice-Presidents, an Executive Committee member, the Director of Finance, and the Director of Youth Divisions; the head coach and the Executive Committee Member of Beşiktaş Jimnastik Kulübü (hereafter 'Beşiktaş'); the President and a player (goalkeeper) of Sivasspor Kulübü (hereafter 'Sivasspor'); the head coach and a player (striker) of Eskişehirspor Kulübü (hereafter 'Eskişehirspor'); and two players (strikers) of Istanbul Büyükşehir Belediyespor ('IBB', currently known as 'Basaksehirspor').

The criminal indictment presented by the Turkish public prosecutor (Indictment No: 2011/598) accused the suspects of two distinctive criminal offences that are established under different legislations. First, the public prosecutor alleged that there were activities that involved both match-fixing ('şike' in

Table 1 The list of games that were the subject of match-fixing activities during the 2010/2011 season in Turkish football

\begin{tabular}{lll}
\hline Games & Date & Division \\
\hline 1. Manisaspor v Trabzonspor & 21.02 .2011 & Super League \\
2. Fenerbahçe v Kasımpașa & 26.02 .2011 & Super League \\
3. Bursaspor v Istanbul Büyükșehir Belediyespor & 06.03 .2011 & Super League \\
4. Gençlerbirliği v Fenerbahçe & 07.03 .2011 & Super League \\
5. Gençlerbirliği v Trabzonspor & 20.03 .2011 & Super League \\
6. Eskișehirspor v Fenerbahçe & 09.04 .2011 & Super League \\
7. Trabzonspor v Bursaspor & 17.04 .2011 & Super League \\
8. Eskișehirspor v Trabzonspor & 22.04 .2011 & Super League \\
9. Fenerbahçe v Istanbul Büyükșehir Belediyespor & 01.05 .2011 & Super League \\
10. Karabükspor v Fenerbahçe & 08.05 .2011 & Super League \\
11. Fenerbahçe v Ankaragücü & 15.05 .2011 & Super League \\
12. Trabzonspor v Istanbul Büyükșehir Belediyespor & 15.05 .2011 & Super League \\
13. Sivasspor v Fenerbahçe & 22.05 .2011 & Super League \\
14. Beșiktaş v Istanbul Büyükșehir Belediyespor & 15.05 .2011 & Turkish Cup \\
15. Diyarbakırspor v Giresunspor & 04.04 .2011 & First League \\
16. Karșıyakaspor v Giresunspor & 18.04 .2011 & First League \\
17. Giresunspor v Mersin Idmanyurdu & 30.04 .2011 & First League \\
\hline & &
\end{tabular}


Turkish) and the payment of incentive bonuses ('teşvik primi' in Turkish), which are criminal offences related to the manipulation of the results of the matches under section 11 of Legislation 6222 on Prevention of Violence and Disorder in Sport, which came into force on April 14th 2011. Second, certain suspects were also alleged to be involved in the formation and activities of 'criminal organisations', defined as an offence under Section 220 of the Turkish Penal Code. Section 220 of the Turkish Penal Code defines the characteristics of a 'criminal organisation': firstly, the presence of (at least) three persons, who come together with an intention to engage in criminal activity. Secondly, a 'criminal organisation' is a hierarchical entity. The existence of hierarchy necessitates a 'leader', who provides directives and orders, and 'members' who act upon them. Finally, there needs to be continuity in the relationship among the members of the organisation.

This distinction between criminal offences under the Turkish law is important in order for one to understand the conviction of the case's individuals. Whilst some of the suspects were later convicted by the courts for both the offences of Legislation 6222, i.e., match-fixing and the payment of incentive bonuses, and section 220 of the Turkish Penal Code, i.e., establishing or being member of a 'criminal organisation', others were convicted of only one criminal offence either under Legislation 6222 or section 220 of the Turkish Penal Code. In particular, the President of Fenerbahçe was accused of establishing and running a criminal organisation composed of both officials of the Club and other actors to manipulate the results of certain matches in order for his club to win the 2010/11 Turkish Super League Championship, which the Club eventually won in the last week of the season. Alleged manipulation involved fixing activities by monetarily rewarding a number of the opponents' players, coaches and team administrators to underperform against Fenerbahçe, and offering payment of incentive bonuses to perform well against Trabzonspor Kulübü (hereafter 'Trabzonspor'), the main rival of Fenerbahçe and an eventual runner-up for the Championship of that season. At the same time, players, match officials and presidents of opposing teams, who accepted money to participate in the fixing of matches, were accused of match-fixing and the payment/receipt of incentive bonuses, under section 11 of Legislation 6222 on Prevention of Violence and Disorder in Sport, but were not accused of involvement in organised crime activities.

Subsequent proceedings of the case have involved criminal lawsuits before the Turkish courts. The original criminal proceedings were before the 16 th High Criminal Court of Istanbul, a special-authorised state court, ${ }^{1}$ and its judgment (Judgment No: 2012/71) was delivered during the 23rd hearing on July 2nd 2012. The court convicted 47 suspects, including the President and the officials of Fenerbahçe, and the head coach and an Executive Committee member of Beşiktaş, for offences under Legislation 6222 and section 220 of the Turkish Panel Code, and acquitted 46 suspects. Subsequently, both the convicted individuals and the public prosecutor appealed against the judgment before the Turkish Supreme Court (5th

\footnotetext{
${ }^{1}$ The 16th High Criminal Court was a special-authorised state court, 'özel yetkili mahkeme’, established by Legislation 5190 in 2004 to replace specialist courts to trial individuals that committed terrorism-related offences.
} 
Criminal Division) which delivered its decision (Judgment No: 2014/516) on January 17th 2014. The Supreme Court upheld the convictions of the President and the one of the Vice-President of Fenerbahçe but quashed the convictions of 31 individuals on the grounds of procedural irregularities related to the Legislation of Criminal Procedural Rules. The Supreme Court also ordered the re-trial of those 31 individuals and appointed the 13th High Criminal Court in Istanbul ${ }^{2}$ for the re-trial procedings as the special-authorised state courts were abolished in Turkey on March 6th 2014. Meanwhile, the individuals whose convictions were upheld requested a stay of execution and a re-trial as well, both of which were accepted by the 13th High Criminal Court effectively allowing them to join the proceedings that commenced on January 13th 2015. The 13th High Criminal Court acquitted all defendants during the 6th hearing on October 9th 2015 (Judgment No: 2015/212). In relation to the offences of Legislation 6222, match-fixing and the incentive bonus payments, the reasoning by the Court was based on the illegality and inadmissibility of evidence that was gathered by the Turkish authorities rather than the examination of actual offences. Because the wiretapping and physical tracking by the Turkish police were initiated in December 2010 prior to Legislation 6222 coming into force (in April 2011), according to the Court, the wiretaps and other physical evidences were not legally obtained by the court order and used to construe offences that legally did not exist, thus rendering the evidence inadmissible (Judgment No: 2015/ 212 , pp. 250-53). The Court also concluded that the illegality and inadmissibility were applicable even after Legislation 6222 came in force, and therefore there was a lack of legitimate evidence to prove the offences of match-fixing and incentive payments (Judgment No: 2015/212, p.251 and 272) while ordering for all evidence obtained by the Turkish authorities to be destroyed (Judgment No: 2015/212, p.305). This judgment is currently subject to a pending appeal before the Supreme Court (5th Criminal Division).

The criminal proceedings of the Turkish courts have had ramifications not only for the individuals relating to the case but also for the affiliated clubs. Both the Turkish Football Federation (TFF) and the Union of European Football Associations (UEFA) initiated disciplinary investigations following the arrests made by Turkish authorities in July 2011. Firstly, the TFF, on August 24th 2011, withdrew Fenerbahçe from participating in the 2011/12 UEFA Champions League competition and allowed Trabzonspor, the runner up for that season, to participate in the competition instead. The TFF Professional Football Disciplinary Committee (PFDC) also initiated disciplinary proceedings against 16 Turkish Super League clubs and individuals that were alleged to be involved in match-fixing activities in the indictment and, on May 6th 2012, a total of 10 individuals were sanctioned with various bans from football-related activities. Amongst them were the Vice-Presidents and the Youth Divisions Director of Fenerbahçe, a board member of Sivasspor, a player (striker) of IBB and a player (striker) of Eskişehirspor (PFDC 2012). The appeals of these individuals were also rejected by the TFF Board of Appeals on June 4th 2012 (TFF 2012). Meanwhile, UEFA's Control and Disciplinary Body (CDB), which had closely monitored both the criminal proceedings before the Istanbul 16th High Criminal Court and the TFF's

\footnotetext{
${ }^{2}$ The 13th High Criminal Court differs from the 16th High Criminal Court of Istanbul as it is a criminal court not a special-authorised court.
} 
disciplinary proceedings, sanctioned both Fenerbahçe and Beşiktaş due to the involvement of their club officials in match-fixing activities (UEFA 2013a). Fenerbahçe was excluded from participating in the next three UEFA club competitions (2013/2014, 2014/2015, and 2015/2016 seasons) for which they would qualify, whilst Beşiktaş was excluded from participating in the UEFA Europa League 2013/14, which the Club had already qualified for. Both clubs appealed against these decisions with the UEFA Appeals Body rejecting Beşiktaş' appeal and reducing the exclusion period of Fenerbahçe from UEFA club competitions to two years (2013/2014, 2014/2015 seasons), and deferring the third season for a probationary period of five years (UEFA 2013b). Both clubs also appealed to the Court of Arbitration for Sport (hereafter CAS), but the decisions of UEFA's Appeals Body were upheld as the CAS panels were adamant that the officials of both clubs conducted or attempted to conduct match-fixing activities (CAS 2013a/A/3256 \& CAS 2013b/A/3258).

\section{Data and methods}

The article is based on a variety of sources of data of a similar nature. Firstly, an analysis of the official legal files of four criminal and seven disciplinary proceedings was conducted. In more detail, our analysis focused on the Indictment of the Public Prosecutor of Istanbul (No. 2011/598), the proceedings before the Istanbul 16th High Criminal Court (No. 2012/ 71), the appeal proceedings before the Turkish Supreme Court (5th Criminal Division No. 2014/516), the re-trial before the Istanbul 13th High Criminal Court (State Court - No. 2015/212), the disciplinary proceedings initiated by the Turkish Football Federation (TFF - No. 111), the two disciplinary proceedings by UEFA $(2013 \mathrm{a}, \mathrm{b})$ and the four arbitration proceedings before the CAS (CAS - 2013a/A/3256, 2013b/A/3258, 2015a/A/4345 and $2015 \mathrm{~b} / \mathrm{A} / 4347)$. These proceedings contain the Turkish police's initial investigation findings, which include excerpts from wiretapped conversations, physical recordings, photographic evidence and ample details on the processes and actors of the matchfixing case. The main limitation of this study is that the legal files used in this research, and in particular the evidence they contain, are the result of law enforcement activity, which in turn is the result of resource restrictions, the competency of agents, organizational priorities, and wider political priorities (see Kinzig 2004).

\section{Findings and analysis}

\section{The process of match-fixing}

A clear and well organised four step process was followed in order for the above mentioned matches to be fixed. The steps included in the process, as well as its peculiarities will be discussed below.

\section{Initial meeting - match selection}

As described within the legal files, the first step in the process of match-fixing was a meeting, between three individuals, the President and the Vice-Presidents of 
Fenerbahçe, which was mostly held in the training ground of the club. In this initial meeting, key topics were discussed, such as which games needed to be fixed, the possibility to manipulate their result and the level of payment to be offered. The matches selected fall under two categories; firstly, matches of Fenerbahçe with competitive balance between the team and its opponent; and secondly, matches with competitive balance between the runner-up teams for the Championship title and their opponents. Competitive balance, the premise that sporting contests must contain elements of unpredictability and thus an uncertain outcome, is a central element to any sporting contest (Freestone and Manoli 2017). In both categories of matches, the existence of a high unpredictability of the result and the subsequent effect its outcome would have on the final ranking of the league table were the main criteria for the selection of particular matches to manipulate.

At this initial meeting, an agreement would be reached on the plan of action to follow in order for the desired results to be achieved, which actors of the 'organisation' to involve in the process of fixing the games, and who to initially approach in the opposion team. Determining the selection of particular actors for the matchfixing process mostly depended upon the actors' ability and the extent of their network to enable the set-up of the fixing, in particular accessing the individuals of the opposition and carrying out the negotiations. Therefore, considering the convictions, although all actors of the 'organisation' were charged with the offence of organised crime under section 220 of the Turkish Penal Code, their convictions for the offences of match-fixing and incentive payments under Legislation 6222 were not related to all 13 games, but only to those games where their direct involvement in conducting activities of fixing or attempting the fix was proven.

\section{Setting up \& gaining access}

Following the initial meeting, the second step of the process involved communicating the plan of action to fix a particular game and the level of payments to be offered in return to the selected actors for each match. Generally, the officials of Fenerbahçe were the first to be contacted and informed about the plans. Then, the other selected actors were contacted and informed to commence the accessing the individuals in the opposition, i.e. players, coaches or team administrators. The above line of action is clearly illustrated in the fixing process of the match against Ankaragücü on May 15th 2011. It was the President who first instructed one of the Vice-Presidents to arrange the manupilation of the game, who then contacted the Director of Youth Divisions to commence the fixing activities (Indictment No: $2011 / 598$ p. 337 , Judgment No: $2012 / 71$, p.83). What is also important to note at this stage is that, since match-fixing was organised for the purposes of sporting success, i.e., Fenerbahçe to win the Championship, depending on the importance of specific matches in regard to the impact of their results on the league standing, the actors of the organisation would be divided into sub-groups in order to facilitate the access to the individuals of the opponents as soon as possible. For instance, for the matches against IBB on May 1st 2011 and Ankaragücü on May 15th 2011 (Indictment No: 2011/598 p. 302 and 337, Judgment No: 2012/71, p.79 and p.84) there were two sub-groups in operation conducting match-fixing activities whereas three sub-groups worked on the match 
against Sivasspor (Indictment No: 2011/598 p. 371, Judgment, pp. 86-87). The sub-groups were operating in coordination with each other in order to avoid approaching the same individuals. This clear division of tasks and targeted individuals can be better illustrated through the following quotes, taken from the wiretapped conversations between the President of Fenerbahçe and the two Vice-Presidents, regarding the match against IBB on May 1st 2015. In the excerpts, the President was trying to get an update on accessing the player of $I B B$ who was known to the actors because he used to play for Fenerbahçe and in one of the matches scored an own goal.

\section{President: How is everything?}

Vice-President 1: Everything is fine, my president. Everybody is in their relevant places...I passed your message to all of them.

P: Him, who scored an own goal?

VP 1: Hmm, I do not know him, he is not my responsibility.

P: Is that so? OK then.

The President calls the other Vice-President.

President: How is it going?

Vice-President 2: Good, good, really good.

P. ...today...what did you do with our one who scored an own goal?

VP 2: Hmm, him, everything fine with him, there is no problem...on Monday... everything is fine not to worry.

(Indictment No: 2011/598 p. 313, Judgment No: 2012/71, p.264)

It is worth underlying that while these initial steps followed in this process resemble the initial steps in both the Belgian (Hill 2009) and the Greek (Manoli and Antonopoulos 2015) case, this highly organised procedure of carefully crafting and managing the division of tasks has not been documented before. All actors were in regular contact with the Vice-Presidents, informing them about their progress. This effective communication ensured that the activities of the subgroups were coordinated and did not overlap. The actors used their personal network to approach the individuals in the opposition teams, making the access to them far from problematic. Commonly, the individuals selected were either players that were represented by the players' agents involved, or former players, managers and officials of Fenerbahçe who were now working for the opponents. 
If at any point a challenge appeared in penetrating the opposition team due to a possible lack of connections, external individuals were approached, for instance a player or a manager who used to either play or work for the opposition, in order for their network in the team to be utilised for the required access to be gained. The initial contact with these individuals was via phone, either text message or call, but followed with a meeting to discuss the details. For instance, in arranging the fix for the match against $I B B$ on May 1st 2011, the unlicensed players' agent of the 'organisation' contacted a player (striker) of $I B B$ to negotiate the fixing. The player was represented by the unlicensed agent and not only gaining access was easy, but also arranging the fix required only two phone calls and an in-person meeting (which took place in a restaurant and was physically recorded by the Turkish Police - Indictment No: 2011/598 p. 302, Judgment No: 2012/71, p.362).

\section{Negotiating the fix}

Once the access to these actors was achieved, the next stage was to negotiate the fix. Negotiations usually took place in meetings held in neutral locations, such as a restaurant or a hotel lobby. In the fixing of the match against $I B B$, arranging the fix involved the negotiations between the unlicensed agent and the player, concerning the currency of the payment. The initial discussion was in relation to the fee of US\$100,000, but then the player changed his preference to $€ 100,000$ Euro. The said player sent a number of texts to the unlicensed agent about this matter, one of which reads: Brother, it is not 100 Dollars but 100 Euro, that's what he said:) (Indictment No: 2011/598 p. 308, Judgment No: 2012/71, p.364). After his request, the following text exchange occurred between the player and the agent:

Player: Brother, have you changed it to $€ 100,000$ ?

Unlicensed players' agent: No, I have not spoken yet, I will go there tonight brother:) Late at night.

Player: I do not accept anything else.

(Indictment No:2011/598 p. 308, Judgment No: 2012/71, pp.364-365)

The negotionations, when a long-term relationship existed between the two members such as a player and his representing agent, were often short and relatively brief. For example, when the same unlicensed players' agent mentioned above was asked to access the player (goalkeeper) of Sivasspor who happened to be also represented by him. The two met in a restaurant in Istanbul and exchanged phonecalls in order to negotiate the fee of US\$300,000 for fixing (Indictment No: 2011/598 pp. 393-394, Judgment No: 2012/71, p.492).

In some occasions the individuals approached (e.g. player, manager or team administator) refused to get involved in match-fixing, despite efforts to convince them. On these occasions, the unsuccessful actors would re-start the process by trying to access other individuals within the opposition teams. In essence, under Legislation 
6222 , once there is an agreement between the actors in place to manipulate a match, the offence of match-fixing is committed; whether the desired result of the game is achieved is secondary and not taken into consideration. If the negotiations failed, i.e., players did not agree to the offer of fixing, or rejected it, then, it is still an offence but classed as 'attempted' under the legislation.

The importance of dividing the organisation into multiple sub-groups for crucial games and approaching different individuals of the opponents simultaneously, thus increasing the possibility of the fix, illustrates the sophistication of the process followed, that involved taking into consideration the possibility that the negotiations might not reach an agreement. This well-organised approach does not resemble either the Belgian (Hill 2009) or the Greek (Manoli and Antonopoulos 2015) case, which followed a less methodical and more spontanteous process.

It is important to note that within the legal files there exists no suggestion of any evidence of use of any threats or force to convince anyone to participate in match-fixing activities, unlike the above mentioned similar match-fixing cases. It is also worth underlining that the legal files do not specify any additional activities by the actors before or during the matches, such as the arrangement and coordination of the referees or interventions into the dressing rooms during half-time, specifically aiming to ensure the desired result is achieved. Nevertheless, considering that Fenerbahçe won all the matches that were subject to match-fixing activities, it can be assumed that the actors were successful in their efforts of manipulating the matches that they targetted.

\section{Post-fix payments}

Payments in the overall process of match-fixing were generally made after each game. The Finance Director released the agreed payments to the Vice-President, who distributed money to the actors involved in the process of match-fixing of each particular match in order to make the actual payouts. Neither the President nor the Vice-Presidents ever made any direct payments. The amounts of the payouts varied, sometimes significantly. For instance, for the match against $I B B$ on May 1st 2011, the player of the opposition was offered and paid $€ 100,000$ (Indictment No: 2011/598 p.303, Judgment No: 2012/71, pp. 79-80). US\$400,000 was on offer for the Ankaragücü match and money was distributed to the two subgroups that were working on the fixing of the game. Eventually, only US $\$ 200,000$ was paid to the individuals who agreed to participate in match-fixing activities, and the remaining US\$200,000 was returned (Indictment No: 2011/598 p.337, Judgment No: 2012/71, pp. 83-84). Both the $€ 100,000$ that went to the striker of $I B B$ and the US\$100,000 used for the Ankaragücü match were subsequently secured by the Turkish Police (Indictment No: 2011/598 p.306 \& 340, Judgment No: $2012 / 71$, p.79 \& p.84). For the Sivasspor match, on the other hand, 400,000 Turkish Lira was offered and paid to the club (Indictment No: 2011/598 p.372 Judgment No: 2012/71, p.87). All payments had been made in neutral locations.

\section{Case peculiarities}

One of the most peculiar and interesting aspects of the football match-fixing process in Turkey was the transfer promise made to some of the players of 
opposing teams as an incentive to participate in the fixing. This previously undocumented activity can be described as 'fixing through the promise of transfer' and it was based upon the exploitation of the position of Fenerbahçe as a club at the apex of Turkish football. Since playing for the Club is highly desirable to many players in Turkey, it was used as leverage in the process of fixing. The promise of a transfer or the expression of interest by the Club was communicated to some of these important players in opposition teams or to their representatives, in order to manipulate the players' phychological state. What is important to note is that the transfer promise was made right before a match, in order for the overall strategy of manimulating the phychological state of the players to work. For example, before the games against Eskişehirspor on April 9th 2011 and Karabükspor on May 9th 2011, the lawyer who worked for Fenerbahçe approached the player of Eskişehirspor and the representative of the player of Karabükspor to discuss their potential transfer to Fenerbahçe (Indictment No: 2011/598 pp. 271 and 323-325 and Judgment No: 2012/71, p.74 and 81). Although the attempt did not work with the player of Eskişehirspor, it was effective with the striker of Karabükspor, who refused to play against Fenerbahçe blaiming his injury sustained in the match a week before. ${ }^{3}$

The overall match-fixing process has some particular characteristics that are worth highlighting (Indictment No: 2011/598 pp.186-191, Judgment No: 2012/71, pp.5762). Firstly, particular measures were taken to avoid detection by the Turkish authorities. For example, mobile phone conversations were very brief and essentially limited to making arrangements for further communication in more secure settings. The specifics of fixing activities were discussed in the calls from landline numbers, which are more difficult to be wiretapped, or in face-to-face meetings. In addition, a particular brand of mobile phones was used, which was believed to assist in avoiding wiretapping by the authorities, and, in the case of meetings, 'safe' locations such as the training ground of Fenerbahçe or the business premises of the actors were often preferred. Secondly, during the conversations, the actors used codewords. The matches to be fixed were referred to as 'farm field', 'construction' and 'court case', the players were called 'builders' or 'defendants', the President was referred to as 'the number one' or 'CEO', and the acceptance of match-fixing was described as 'drinking coffee' (Indictment No: 2011/598 pp.190-200, Judgment No: 2012/71, p.61). Thirdly, the payments were recorded in Fenerbahçe's accounts under a specific category of 'expenses' that disguised their true nature. Often, the payments were classified as repayments of personal loans made to the club by the Vice-Presidents or payments for match tickets (Indictment No: 2011/598 pp.189, Judgment No: 2012/71, p.60).

\section{The key actors of match-fixing}

The analysis of the data of the Turkish legal files suggests that a number of individuals were involved in the manipulation of matches during the scandal, a number of whom were convicted for their involvement and in fact charged for their role in the 'criminal organisation' of match-fixing that was led by the President of Fenerbahçe. In particular,

\footnotetext{
${ }_{3}^{3}$ What is important to note that the player was also eventually signed by Fenerbahçe in the Summer transfer window.
} 


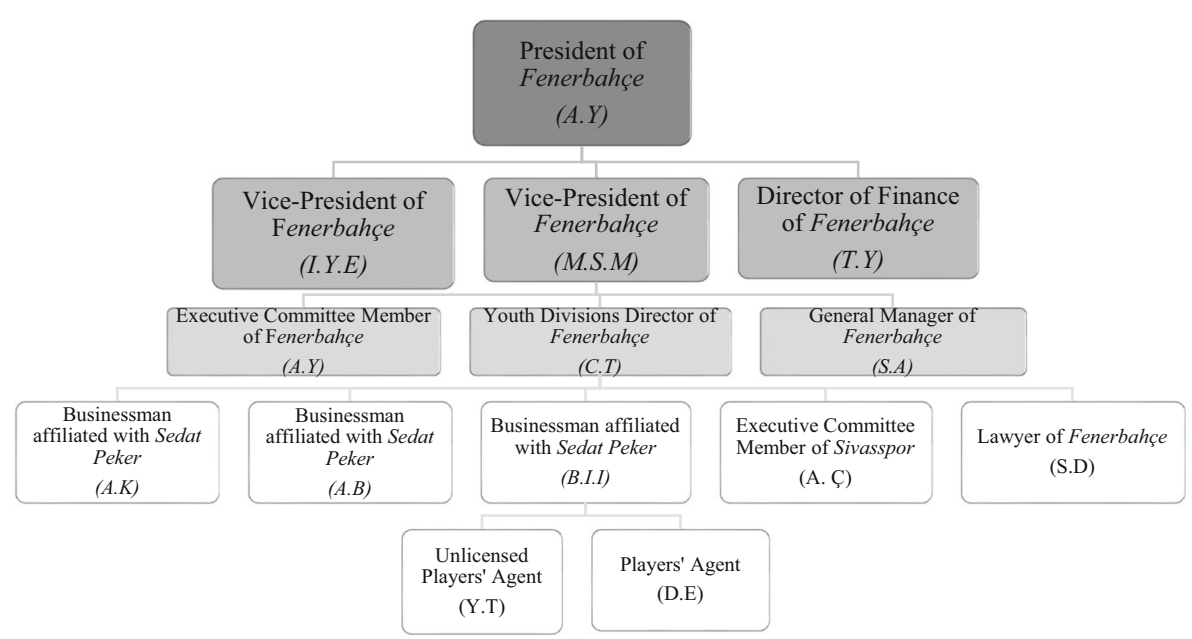

Fig. 1 The structure and the primary actors of the criminal organisation run by the President of Fenerbahçe

the criminal indictment (No: 2011/598, pp.186-191), the decision of the Istanbul 16th High Criminal Court (Judgment No: 2012/71, pp.57-62) and the appeal judgment of the Turkish Supreme Court (Judgment No: 2014/516, pp. 16-17) all detailed the structure of this 'criminal organisation' that conducted match-fixing activities (Fig. 1). ${ }^{4}$

Examining the legal files further, while taking the classifications and similar investigations of match-fixing processes and actors presented by Hill (2009) and Manoli and Antonopoulos (2015) into consideration, the key actors involved in the match-fixing process will be discussed below. For the purposes of our analysis, the individuals involved in the organisation in question are described as 'primary actors' of the case as they were convicted of both offences under the Legislation 6222 and section 220 of the Turkish Panel Code. The individuals who were convicted for match-fixing activities as per the Legislation 6222 but not for involvement with the 'criminal organisation' are referred to as 'secondary actors' of the case. In other words, the conviction for one or both offences is the distinguishing factor between the two categories of actors.

\section{Primary actors}

The primary actors in the Turkish football match-fixing scheme included:

- The President of Fenerbahçe: The 'criminal organisation' was established and led by the President of Fenerbahçe. As the leader of the organisation, according to the

\footnotetext{
${ }^{4}$ The criminal organisation presented in the Figure 1 is constructed through the Turkish legal files and composed of individuals who were convicted for their involvement with the organisation by both courts, the 16th High Criminal Court in Istanbul and the Turkish Supreme Court (5th Criminal Division). Additionally, although the General Manager of Fenerbahçe passed away during the appeal proceedings and, thus, his conviction was consequently quashed by the Turkish Supreme Court (5th Criminal Division) (Judgment No. 2014/516, p.36), the appeal judgment acknowledged and referenced his role within the organisation (Judgment No. 2014/516, p.17).Therefore, his role is also acknowledged within the structure of the organisation in Figure 1.
} 
legal files, the President was the key actor making strategic decisions regarding the matches to be fixed and the level of payments to be offered in return. Manoli and Antonopoulos (2015) consider individuals in this kind of position both the primary actors and initiators of the overall match-fixing process, or, according to Hill (2009), they are the leaders of the match-fixing 'organisations'. The President had a hierarchical relationship with the members of the organisation, with the characteristics of this relationship underlined within the legal files. In more detail, his decisions were never questioned by the others and his orders to manipulate the matches were directly acted upon despite their criminal nature (Judgment No: 2012/ 71, p.58, Judgment No: 2014/516, p. 17). Moreover, payments were released to the members only upon his the directives (Judgment No: 2012/71, p.59, Judgment No: 2014/516, p. 17), while the President contacted and met primarily with the VicePresidents and rarely engaged with other co-conspirators (Judgment No: 2012/71, p.59, Judgment No: $2014 / 516$, p. 17), as it was described above in the process of the fixing.

- The Vice-Presidents of Fenerbahçe: Two Vice-Presidents were close confidants of the President, operating directly below him as the seconds-in-command within the hierarchy of the organisation. They communicated the orders of the President to others within the organisation, coordinated the fixing activities of the group during the overall process of match-fixing, and reported back to the President. One of the Vice-Presidents was also directly responsible for managing the payments that were made in return for the fix. In particular, he organised the distribution of money to the others in the organisation and coordinated payments to the opponents.

- The Finance Director of Fenerbahçe: Working in conjunction with the VicePresidents, the Director of Finance was responsible for releasing payments from the accounts of the club to the Vice-President who was in charge of money distribution. The Finance Director also recorded all payments made and ensured they were all accounted within the books of the club in a manner that disguised their true nature.

- Other actors of the organisation / Intermediaries: This category of actors within the organisation comprises of two distinct groups of individuals. The first group consisted of three club officials of Fenerbahçe, operating directly below the Vice-Presidents, a member of the Executive Committee who is also the President's brother, the Club's General Manager and the Director of Youth Divisions. The second group entailed people who were not officially affiliated with the Club and included three businessmen, the Executive Committee Member of Sivasspor, a lawyer that was handling some of the legal work of Fenerbahçe, an unlicensed players' agent and a licensed players' agent. These actors were named as 'facilitators' by Manoli and Antonopoulos (2015), whilst Hill (2009) classified them as 'runners' who facilitate access to players, coaches and team administrators of oppositions, and are directly involved in negotiations and the delivery of payments during the process of match-fixing. A key attribute of these individuals was their established experience and extended network within Turkish football which was critical in performing their duties within the structure of the organisation (Judgment No: 2012/71, p.59, Judgment No: 2014/516, p.17). In addition, the businessmen involved in the organisation had historically held close links with the prominent Turkish 
'mafia' leader, Sedat Peker, who also ran his own criminal network conducting a variety of criminal activities (Judgment No: 2012/71, p.59). Sedat Peker was historically the subject of police investigation for the operation of his 'criminal organisation' in Turkey and was convicted of a number of criminal offences. The President of Fenerbahçe had ties with Peker, while the 'criminal organisation' that manipulated the results of Fenerbahçe matches includes a number of individuals either directly involved in Peker's organisation or linked to it (Indictment No: 2011/598, pp. 192-200; Judgment No: 2012/71, pp. 62-63; Judgment No: 2014/516, p.16). For instance, the businessmen who were involved in the 'criminal organisation' led by the President of Fenerbahçe had direct links with Sedat Peker (see Fig. 1). In particular, one of the businessmen (B.I.I) was previously investigated (and in fact arrested) for being part of Peker's organisation (Indictment No: 2011/598, p. 192; Judgment No: 2012/71, p. 62). Additionally, the Club lawyer, who was also part of the 'criminal organisation' led by the President of Fenerbahçe, had links with Sedat Peker whom he had represented in the past (Indictment No: 2011/598, p. 193; Judgment No: 2012/71, p. 63). Interestingly, and despite Peker's ties with 'mafia' type activites, his connection to the Turkish match-fixing case was limited to being used by other members of the 'organisation' indirectly and often unknowingly, primarily for his reputation and his intimidation capital (Indictment No: 2011/598, p. 193; Judgment No: 2012/71, p. 63).

A hierarchical relationship existed within each of the two groups of individuals as well. The club officials worked closely with the Vice-Presidents assisting them in making strategic decisions related to specific activities required in fixing the games, such as who to initially contact in the opposition team (specific players, coaches or team administrators) and the way of physical payments to be arranged. The club officials also assisted in deciding which members of the organisation would work for the fixing of individual games and often became a communication channel between the Vice-Presidents and the other members throughout the fixing process, although the Vice-Presidents communicated directly with every member involved in the process as well.

\section{Secondary actors}

The secondary actors of the math-fixing process included players, presidents, and club officials of opposing teams. The diversity of these actors was potentially due to the fact that attempts were made to manipulate the result of a high number of matches and in order to do so a high volume of secondary actors were targeted in order for the expected result to be achieved. As previously underlined, the secondary actors were not part of the criminal organisation directly, and were thus convicted only for match-fixing activities as per Legislation 6222 but not for involvement with the 'criminal organisation'; they nevertheless played an active and important role in the overall process of match-fixing.

Players were key secondary actors due to their power to manipulate the result of a match, with primary actors specifically targeting goalkeepers and strikers. For instance, the two strikers of $I B B$, the striker of Eskişehirspor and the goalkeeper of Sivasspor 
were all approached and eventually agreed to take part in the fixing of respective games and were subsequently convicted for math-fixing (Judgment No: 2012/71, pp.580669). Considering that the objective of match-fixing is (initially) sporting, i.e. for Fenerbahçe to win each match and eventually the league title, the choice of players (goalkeepers and strikers) was logical as they are best positioned to directly influence the result of a match (Indictment No: 2011/598 p.190, Judgment No: 2012/71, p.61). The influence these players can have on the outcome of a match is best illustrated in the following excerpt of a wiretapped conversation, in which the Sivasspor's striker discusses his performance in the match after its completion.

Striker: What can I do, we made Fenerbahçe the champions and I am going.

Person X: My son, you should have just headed the ball to score but you kicked it, you do not kick.

Striker: Why should I score, I did not go there to score...I was there just to be there...

(Indictment No: 2011/598 p. 387, Judgment No: 2012/71, p.483)

The presidents and the club officials of the oppenents were mainly approached to facilitate the access to the players. However, they were not the only officials of opponents used in the process; the coaching team of an opponent, namely the head coach of Eskişehirspor and his assistant were involved in fixing both the matches of Eskişehirspor and the match against Sivasspor (Indictment No: 2011/ 598 pp.276, 283 and 374, Judgment No: 2012/71, p.287, 337 and 350). The head coach used to work for Sivasspor and in the past played for Fenerbahçe. Therefore, he was personally known by the primary actors who utilised his network to access the players in the teams and to fix the games. The primary actors' ability to reach out an exented number of secondary actors in the process underscores the strength of their network in Turkish football.

\section{Discussion}

A number of observations can be made on the basis of the data obtained on the Turkish match-fixing scandal. Firstly, unlike the relatively recent case of football match-fixing scandal in Greece also known as Koriopolis (a pun name on the Italian scandal Calciopoli and the Greek word 'korios' or phone-tap), which involved match-fixing networks with a naturally defined horizontal 'structure', with participants on these networks many times acting on improvisation, and individuals or small groups forming temporary collaborations in order for their shared objective to materialise (Manoli and Antonopoulos 2015), in Turkey a different image emerges. Specifically, the business of Turkish match-fixing points towards a relatively rigid organisation, coordination, hierarchy and so on. The perception that the match-fixing structure is a criminal organisation is affected by 
the involvement of the hierarchical structure that has existed as a legal business, i.e. Fenerbahçe, in an illegal scheme.

Secondly, although we are not in the position to verify the root and nature of the relationship between and among the various actors involved in the matchfixing scheme, what can be safely argued is that at the core of many of these collaborations lie the legitimate business connections that are forged within Fenerbahçe. The club is effectively the context in which legal business relationships transform into illegal business relationships, and the platform upon which 'loyalty' (functional for match-fixing activities and necessary for secrecy) is borrowed (von Lampe 2007). What von Lampe (2007) calls a 'social microcosm' of illegal entrepreneurs is of critical importance to the success of match-fixers. In contrast to other contexts, such as -for instance- Belgium, the primary actors are not 'foreigners' (Hill 2010) but native individuals, who are embedded in the Turkish football industry. As such they cannot be perceived as exogenous to the sport industry which are trying to infiltrate in order to make profit. Rather they are endogenous individuals who run legitimate companies and who would thus have been cleared by relevant Turkish Government regulations, such as the Fit and Proper test. ${ }^{5}$ As a result, a question can be raised on the potential introduction of similar Government regulations as regards their applicability on such occasions, since, as it is illustrated in this case, match-fixing is not always the product of 'organised criminals' that infiltrate sport, but rather a criminal activity organised by the individuals embedded in the sport.

When intermediaries, who are not directly related to the Club, are involved in the match-fixing process, they allow for the expansion of the reach of the hierarchical structure, that is the football club itself. The lack, however, of formal structure and permanence among those intermediaries acts as a self-protective mechanism to prevent detection through the control of the flow of information about the important, core actors involved in the scheme. As we saw, for instance, neither the President nor the Vice-Presidents ever paid those involved in matchfixing directly. The embeddedness of the match-fixing actors and process in legal businesses (i.e. Fenerbahçe) meant that payments for match-fixing activities were absorbed relatively easily in the normal workings of the club. As mentioned earlier, payments to individuals involved in match-fixing were recorded under the club accounts as the repayments of the club's personal borrowings from the Vice-President. The case of match-fixing in Turkey offers yet another example of how legitimate businesses provide for a very convenient (and already existing) setting for criminal finances management (see Kleemans and Van de Bunt 2008).

Many of the match-fixing activities described earlier in this article took place within the confines of the corporation that is Fenerbahçe, which afforded a relatively low visibility. Moreover, many of the match-fixing activities involved actions of numerous individuals and departments within the particular football club, resulting in a diffusion of the responsibility (see Ruggiero 1996). The particular case of football match-fixing in Turkey exemplifies the blurred

\footnotetext{
5 The Fit and Proper test for Approved Persons is a government introduced test aiming to prevent corrupt or untrustworthy individuals from serving on the board of sporting organisations (Manoli and Antonopoulos 2015).
} 
boundaries between 'organised crime' and 'corporate crime'. There is an overlap between 'corporate crime' and 'organised crime', making it extremely difficult, if not impossible, to distinguish one from the other. It has been suggested that the two are variants of the same type of crime and as such they should be analysed jointly (von Lampe 2016; van Duyne and Block 1994). In some cases, the ways legitimate corporations, such as Fenerbahçe, operate would justify such joint analysis. There is a symbiosis between criminal businesses and legitimate corporations exemplified not only by the criminal activities in which Fenerbahçe officials/employees were involved in within the confines of the legal business but also relevant activities within a criminal network that transcended the corporate boundaries of the club.

Our account on Turkish match-fixing offered elements of the social organisation of Turkish match-fixing on the basis of the 'Şike Davası' scandal during the 2010/2011 football season and highlighted that the phenomenon of match-fixing internationally can take diverse forms some of which are potentially yet to be uncovered (see Di Ronco and Lavorgna 2015). Clearly, additional research on the topic is necessary.

Acknowledgements The authors would like to thank the two anonymous reviewers, Georgios Papanicolaou, and Klaus von Lampe for their helpful comments on an early draft of this article. The review process for this article was handled entirely by the former Editor-in-Chief of Trends in Organised Crime, Klaus von Lampe.

Compliance with ethical standards This article does not contain any studies with human participants or animals performed by any of the authors.

Conflict of interest Authors declare that they have no conflict of interest.

Open Access This article is distributed under the terms of the Creative Commons Attribution 4.0 International License (http://creativecommons.org/licenses/by/4.0/), which permits unrestricted use, distribution, and reproduction in any medium, provided you give appropriate credit to the original author(s) and the source, provide a link to the Creative Commons license, and indicate if changes were made.

\section{References}

Appeal Judgment of the Turkish Supreme Court ( $5^{\text {th }}$ Criminal Division), No: 2014/516

Başaran K (2013) Arkadan Müdahale 3 Temmuz Şike Davası. İletişim Yayınları, Istanbul

Brooks G, Aleem A, Button M (2013) Fraud, corruption and sport. Palgrave Macmillan, Basingstoke

Carpenter K (2014) Match-fixing: framing the fight-back. Int Cent Sports Secur J 2(4):62-69

CAS 2013a/A/3256 Fenerbahçe Spor Kulübü v. UEFA

CAS 2013b/A/3258 Besiktas Jimnastik Kulübü v. UEFA

CAS 2015a/A/4345 Trabzonspor Sportif Yatirim A.S v. UEFA

CAS 2015b/A/4347 Fenerbahçe Spor Kulübü v. Trabzonspor A.S. and UEFA

Di Ronco A, Lavorgna A (2015) Fair play? Not so much: corruption in the Italian football. Trends in Organ Crime 18(3):176-195

Dijkstra HP, Van Dyk N, Schumacher YO (2016) Can I tell you something? I'm doping.... Br J Sports Med 50(9):510-511

Erkin A (2015) Sarı Lacivert Öfkeli Adam: Aziz Yıldırım. Kırmızı Kedi Yayınevi, Istanbul

European Commission (2012) Match-fixing in sports: a mapping of criminal law provisions in EU27.

European Commission, Brussels 
Feltes T (2013) Match-fixing in Western Europe. In: Haberfeld M, Sheehan D (eds) Match-fixing in international sports. Existing processes, law enforcement, and preventive strategies. Springer, New York, pp 15-30

FIFA (2017) Turkey: Men's Ranking. Available at [http://www.fifa.com/fifa-world-ranking/associations/association= tur/men/index.html]

Fincoeur B, van de Ven K, Mulrooney KJD (2014) The symbiotic evolution of anti-doping and supply chains of doping substances. Trends Organ Crime 18:229-250. https://doi.org/10.1007/s12117-014-9235-7

Freestone CJ, Manoli AE (2017) Financial fair play and competitive balance in the premier league. Sport Bus Manag: Int J 7(2):175-196

Haberfeld M, Sheehan D (eds) (2013) Match-fixing in international sports: existing processes, law enforcement and prevention strategies. Springer, New York

Hill D (2009) How gambling corruptors fix football matches. Eur Sport Manag Q 9(4):411-432

Hill D (2010) The fix: soccer and organised crime. McClelland \& Stewart, London

Hill D (2015) Jumping into Fixing. Trends Organ Crime 18(3):212-228

Indictment of Public Prosecutor of Istanbul, No: 2011/598

Jennings A (2016) The dirty game: uncovering the scandal at FIFA. Arrow Books, London

Judgment of the $16^{\text {th }}$ High Criminal Court of Istanbul, No: 2012/71

Judgment of the $13^{\text {th }}$ High Criminal Court of Istanbul, No: 2015/212

Kinzig J (2004) Die rechtliche Bewältigung von Erscheinungsformen organisierter Kriminalität. Duncker and Humblot, Berlin

Kleemans E, Van de Bunt HG (2008) Organised crime, occupations and opportunity. Glob Crime 9(3):185-197

Legislation 6222 on Prevention of Violence and Disorder in Sport ("6222 Sayili Sporda Siddet and Duzensizligin Onlenmesine Iliskin Kanun")

Manoli AE, Antonopoulos GA (2015) 'The only game in town?': Football match-fixing in Greece. Trends Organ Crime 18(3):196-211

Manoli, A. E., Antonopoulos, G. A., \& Bairner, A. (2017) The inevitability of corruption in Greek football. Soccer Soc. Early access online: https://doi.org/10.1080/14660970.2017.1302936

Mutschke R (2013) Preface: match-manipulation by organised crime groups. In: Haberfeld M, Sheehan D (eds) Match-Fixing in International Sports: Existing Processes, Law Enforcement and Prevention Strategies. Springer, New York, pp ix-xiii

O'Leary J (2013) Drugs \& Doping in Sports. Routledge, London

Paoli L, Donati A (2014) The sports doping market. Springer, New York

Ruggiero V (1996) Organised and corporate crime in Europe. Dartmouth, Aldershot

Spapens T, Olfers M (2015) Match-fixing: the current discussion in Europe and the case of the Netherlands. Eur J Crime Crim Law Crim Justice 23(4):333-358

TFF Professional Football Disciplinary Committee (2012), The decision of meeting no. 111 on 06.05.2012. Available online from http://www.tff.org/default.aspx?pageID=246\&ftxtID=15123 [Accessed 18.10.2017]

UEFA (2013a), Decisions on Beşiktaş, Fenerbahçe, Steaua. Available online from http://www.uefa. com/insideuefa/disciplinary/news/newsid=1967131.html [Accessed 18.10.2017]

UEFA (2013b), Beşiktaş and Fenerbahçe appeal decision. Available online from http://www.uefa. $\mathrm{com} /$ insideuefa/disciplinary/news/newsid=1971905.html [Accessed 18.10.2017]

Uzun S (2015) Baykal Kaseti, Dink Cinayeti ve Diğer Komplolar. Kırmızı Kedi Yayınevi, Istanbul

van Duyne PC, Block A (1994) Organised cross-Atlantic crime. Crime Law Soc Chang 22(2):127-147

von Lampe K (2007) Criminals are not alone: some observations on the social microcosm of illegal entrepreneurs. In: van Duyne P, Maljevic A, van Dijck M, von Lampe K, Harvey J (eds) Crime business and crime money in Europe. Wolf Legal Publishers, Nijmegen, pp 131-156

von Lampe K (2016) Organised Crime. Sage, Los Angeles 